\title{
Meteorological tsunamis on the US East Coast and in other regions of the World Ocean
}

\author{
Ivica Vilibić • Sebastian Monserrat • Alexander B. Rabinovich
}

Received: 31 July 2014/Accepted: 31 July 2014/Published online: 27 August 2014

(C) Springer Science+Business Media Dordrecht 2014

\section{Introduction}

Meteorological tsunamis (meteotsunamis) are significant, even devastating, sea level oscillations (seiches) at the coast with the same frequencies and spatial scales as typical tsunami waves, related not to seismic activity, volcanic explosions or submarine landslides, but to atmospheric forcing: atmospheric gravity waves, pressure jumps, frontal passages, squalls, etc. (Monserrat et al. 2006). In recent years, this phenomenon has attracted much attention, because several destructive meteotsunamis occurred in various parts of the world oceans, in particular in Spain, Croatia, Japan and the East Coast of the USA.

Actually, strong sea level oscillations associated with atmospheric activity were known in some countries for a long time. These oscillations are called "abiki" and "yota" in Japan, "rissaga" or "resaca" in Spain, "šćiga" in Croatia, "marrubbio" or "marrobbio" in Sicily, "milghuba" in Malta, "Seebär" in Baltic countries, "death waves" in Western Ireland and "inchas" and "lavadiads" in the Azores and Madeira islands (cf. Monserrat

I. Vilibić $(\bowtie)$

Institute of Oceanography and Fisheries, Šetalište I. Meštrovića 63, 21000 Split, Croatia

e-mail: vilibic@izor.hr

\section{S. Monserrat}

Institute for Advanced Studies IMEDEA (CSIC-UIB), Esporles, Spain

S. Monserrat

Department of Physics, University of the Balearic Islands, Ctra. Valldemossa, Km. 7.5,

Palma de Mallorca, Spain

A. B. Rabinovich

P.P. Shirshov Institute of Oceanology, Russian Academy of Sciences, 36 Nakhimovsky Pr., Moscow, Russia

A. B. Rabinovich

Fisheries and Oceans Canada, Institute of Ocean Sciences, 9860 W. Saanich Rd., Sidney, BC, Canada 
et al. 2006; Rabinovich, 2009). Nomitsu (1935) was probably the first who indicated the deep meaningful relation of seismically generated tsunamis and "tsunamis" of the atmospheric origin. Defant (1961) introduced the term "meteorological tsunamis" and suggested the consanguinity of extreme seiches observed in various coastal regions. Nevertheless, little attention was paid to this phenomenon by specialists in natural hazards till the middle of the 1990s. Usually, it was considered to be a very local effect occurring in a few particular bays or harbours: Nagasaki Bay in Japan (Hibiya and Kajiura 1982; Akamatsu 1982), Ciutadella Harbour in Menorca Island, Balearic Islands, Spain (Tintoré et al. 1988; Monserrat et al. 1991; Gomis et al. 1993), Longkou Harbour in China (Wang et al. 1987), Vela Luka and some other bays in Croatia (Hodžić 1979/1980; Orlić 1980) and Mazaro del Vallo harbour on the western coast of Sicily (Colucci and Michelato 1976; Candela et al. 1999). The publications of Rabinovich and Monserrat $(1996,1998)$ attracted the interest of tsunami scientists to this type of oscillation. Both meteotsunamis and seismically generated tsunamis can arrive suddenly and without warning, and with comparable destructive effect. For these reasons, investigating both of these types of waves has considerable merit.

In the following years, comprehensive studies of meteorological tsunamis were done in various countries of the world oceans, in particular in Spain (Monserrat et al. 1998; Liu et al. 2003; Jansà et al. 2007), Mexico (González et al. 2001), New Zealand (Goring 2005; Vennell, 2007), Netherlands (de Jong et al. 2003; de Jong and Battjes 2004) and especially in Croatia (Vilibić et al. 2004; Vilibić 2005; Belušić et al. 2007).

Probably, the strongest ever observed meteotsunami occurred in Vela Luka (Croatia), a small town hidden in a bay on Korčula Island in the Adriatic Sea. In the early morning of 21 June 1978, the sea suddenly began to oscillate, flooding the streets and destroying boats and port constructions. Tsunami-like waves with trough-to-crest heights of up to $6 \mathrm{~m}$ (!) and periods of about $18 \mathrm{~min}$ appeared during relatively nice weather and without any warning, resulting in the greatest marine natural disaster in the modern history of Croatia, with estimated damage of 7 million US dollars at that time (Vučetić et al. 2009). Subsequent scientific investigations identified the meteorological origin of this event (Hodžić 1979/1980; Orlić 1980; Vučetić et al. 2009; Orlić et al. 2010). Thirty years later, on 19-21 June 2008, the First International Symposium on Meteotsunamis: "30th Anniversary of the Great Flood of Vela Luka (21 June 1978)" took place in Vela Luka. A collection of papers presented at this symposium, together with a few additional papers on the same topic, was published in a special issue of Physics and Chemistry of the Earth (Rabinovich et al. 2009). The issue, which included 12 papers with the authors representing Argentina, Australia, Brazil, Canada, Croatia, France, Italy, Malta, New Zealand, Russia, Spain and the United Kingdom, covered various aspects of meteorological tsunamis, beginning with the examination of satellite images of meteorological features favourable for meteotsunami generation, through the documentation of meteotsunamis in various regions of the World Ocean, to the creation and testing of the meteotsunami detection algorithms that may be used in future warning systems.

The principal aspect of the problem that became evident after this symposium and publication of associated papers is the necessity to take into account the threat of meteotsunamis in existing and future marine warning systems. Such systems began to be developed in Spain (Marcos et al. 2009; Renault et al. 2011) and Croatia (Šepić et al. 2009; Šepić and Vilibić 2011). Several destructive events that occurred on the East Coast of the USA demonstrated the high risk of meteorological tsunamis and the importance of such a system for this particular region. On 3-4 July 1992, a devastating ocean wave, induced by a propagating squall line, hit Daytona Beach (eastern Florida) and injured 75 people 
(Churchill et al. 1995; Sallenger et al. 1995). A similar event occurred on 25 March 1995 when a train of atmospheric gravity waves generated a 3-m high ocean wave on the western coast of Florida (Paxton and Sobien 1998). Strong atmospherically induced sea level oscillations were observed along the north-eastern coast of the USA (Donn and McGuinness 1960; Donn and Balachandran 1969) and on the south-eastern coast of Newfoundland (Mercer et al. 2002; Mecking et al. 2009).

Probably the critical event was a meteotsunami generated on 28 October 2008 by propagating atmospheric gravity waves. Destructive ocean waves with a period of $\sim 20 \mathrm{~min}$ and wave heights of $4 \mathrm{~m}$ hit Boothbay Harbor on the coast of Maine, USA (Vilibić et al. 2014). This event was the reason why the National Oceanic and Atmospheric Administration (NOAA), USA, decided in early 2011 to issue a funding opportunity focused on research of meteotsunamis along the US coastline, proposing the research project "Towards a Meteotsunami Warning System along the US Coastline (TMEWS)" to bring the research focus on meteorological tsunamis occurring in this region with a future goal to create the Meteotsunami Warning System in the frame of a general Tsunami Warning System for the Atlantic coast. The project merged together a multidisciplinary international group of oceanic and atmospheric scientists from several countries. The research activity of this group in 2011-2013 brought new knowledge on US meteotsunamis and produced an embracive and comprehensive set of papers presented at the meteotsunami session of the 2012 AGU Fall Meeting in San Francisco. This set of papers, together with some other papers presented at this session and additional papers on the same subject from various countries, has formed the current topical issue on meteotsunamis.

In the frame of one issue, it is difficult to reproduce all aspects of the problem; nevertheless, this issue (the second special issue on meteotsunamis!) discusses a high variety of scientific questions associated with such events. A meteotsunami is a complicated phenomenon that is highly variable in time and space. It is well established now that meteotsunami is a multiresonant phenomenon; destructive events occur only when a coincidence of several crucial factors takes place (Monserrat et al. 2006). If, for example, a strong atmospheric disturbance travels over a region, but slightly out of resonant conditions, the final generated wave may be quite weak, and vice versa, even not a very strong disturbance may create a strong response in the resonant case (Vilibic 2008). Also, the persistence of the atmospheric air pressure disturbance over long distances requires very special conditions in the atmosphere, associated with so-called wave ducting (Monserrat and Thorpe 1996) in the lower troposphere or with a self-sustainable propagating waveCISK cell (Belušić et al. 2007) — and even a small portion of strong atmospheric disturbances, being nondissipative over hundreds of kilometres or more, are capable to generate destructive meteotsunami waves in particular areas of the ocean.

To determine whether the conditions are favourable or not, a modern measuring technique with high temporal and spatial resolution is required. As NOAA modernized its tide gauge network in 2005, just after the 2004 Sumatra earthquake and tsunami (that was recorded on the Atlantic coast of the USA; see Thomson et al. 2007), a large amount of new data became available for research and for getting insight into mesoscale properties of both atmospheric disturbances and ocean meteotsunami waves. In addition, fast development of instrumentation techniques and their widespread installation, not only by governmental agencies but also by non-governmental organizations, schools, etc., allowed for better in-depth research of different stages of meteotsunami generation and dynamics. Last but not least, the atmospheric mesoscale models have rapidly evolved during recent years (e.g. Weather and Research Forecasting model, WRF, Skamarock and Klemp 2008), being 
capable of quantitative reproduction of the source mechanisms in the atmosphere (e.g. Tanaka 2010; Renault et al. 2011). Therefore, the execution of the NOAA-funded research activities was timely and resulted in new knowledge, with some papers already published (Pasquet et al. 2013; Pasquet and Vilibić 2013) and some of them being a part of this special issue.

It should be highlighted that the frequency of the meteotsunami occurrence and their worldwide distribution, as well as their strength and destructive effects, seem to have been previously underestimated. As was indicated above, meteotsunamis were considered as some local phenomena for a long time, observed only at specific sites in a few countries (Spain, Croatia, Japan, Italy, Russia, USA, Malta and China). The publication of the first meteotsunami issue (see Rabinovich et al. 2009) considerably widened the geography of this event: significant meteotsunamis were found to also occur in Brazil, Argentina, Canada, New Zealand and the United Kingdom. The second issue expands the observational region of meteotsunamis even wider: substantial, even destructive, events were recorded on the Atlantic coasts of France, Spain and Portugal, on the western coast of Australia and in South Africa. In general, from the papers presented in this issue, we can conclude that definitely there are some "hot spots", i.e. specific sites where meteorological tsunami is observed more often and have larger heights; at the same time, we can see that meteotsunamis can occur in almost all areas of the world oceans and cannot be considered as a very rare, extraordinary event.

Several strong meteotsunamis occurred in the first half of 2014: (1) the meteotsunami of 9 February 2014 that hit the world's longest beach, the Praia do Cassino (literally Casino Beach) in Rio Grande, Brazil, deeply inundating the beaches in the area and flooding and damaging the parked cars; (2) the squall-generated meteotsunami of 29 March 2014 at Panama City, north-western coast of Florida, USA, with a measured wave height at tide gauges of $120 \mathrm{~cm}$, damaged the beach infrastructure; (3) destructive meteotsunami of 25 June 2014 in the middle Adriatic Sea where 3-m waves and 10 knot currents were witnessed in some bays and inlets of Croatian islands; (4) a meteotsunami near the northwestern coast of the Black Sea where on 27 June 2014 a 2-m wave suddenly hit beaches in the Odessa region, Ukraine, injuring 15 people.

All four of these events took place when the current issue was already in preparation; however, once again these events demonstrate the importance of the meteotsunami phenomenon and the necessity to elaborate the corresponding warning systems.

Altogether, 15 papers have been submitted to this special issue; eight of them deal with different aspects of meteotsunamis along the US East Coast and in the region of the Great Lakes, including one paper introducing a new methodology in meteotsunami research based on probabilistic analysis already known in the tsunami science. Seven more papers are documenting meteotsunamis in various coastal areas in the world oceans. All continents, except Antarctica, have been covered, with the authors representing 11 countries.

\section{Meteotsunamis along the US coastline}

The paper by Whitmore and Knight emphasizes the necessity of meteotsunami research along the US coast, including design and creation of a meteotsunami warning system, which led to the NOAA funding opportunity issued in 2011. In the second part of the paper, the authors use results provided by the TMEWS project to investigate the generation of meteotsunami waves during the 2008 Boothbay meteotsunami event based on the 
NTWC $^{1}$ tsunami forecasting model. They evaluate the sensitivity of the model to the meteotsunami source characteristics, specifically to the speed, wavelength and direction of the atmospheric disturbance. Results of their study show that the observed impact can be re-created through numerical modelling when the pressure disturbance period roughly matches the resonant period of the respective harbour.

A thorough investigation of atmospheric conditions during the 2008 Boothbay meteotsunami event is done by Vilibić et al. All available atmospheric and oceanic data, products and documents are used to reproduce the source mechanism with a state-of-the-art meteorological model. The authors assume that internal gravity waves, ducted in the lower troposphere and travelling onshore, may be the source mechanism for the creation of considerable oceanic waves through the Proudman resonance. Also, they found that the existing operational observation systems are ineffective for capturing ground disturbances due to too coarse sampling.

The research of atmospheric conditions existing during the 2008 Boothbay event was continued by Horvath and Vilibić, who performed a large number of numerical sensitivity experiments based on the WRF model to examine the effect of varying initial and lateral boundary conditions, nesting strategy and simulation lead time. They also investigated the influence of atmospheric microphysics and convective parameterizations on the model results and found that the WRF model is applicable only to very short-range forecasting and, what is more, to most advanced parameterizations and high-resolution grid spacing.

Šepić and Rabinovich investigated meteotsunami waves generated in the Great Lakes, Chesapeake Bay, and on the Atlantic coast of the USA by the 'derecho' (a rapidly moving line of convectively induced thunderstorms) of 29-30 June 2012 that devastatingly propagated over north-eastern regions of the USA. High-precision sea level records from the updated NOAA tide gauge network, together with the NOAA and ASOS ${ }^{2}$ air pressure and wind records, enabled authors to examine physical properties and temporal/spatial variations of the generated waves. The findings of the paper indicate that the generation mechanisms of extreme seiches in the basins under study are significantly different: energetic winds play the main role in seiche formation in Chesapeake Bay, atmospheric pressure disturbances are most important for the Atlantic coast, and the combined effect of pressure oscillations and wind is responsible for pronounced events in the Great Lakes.

Another strong meteotsunami event generated by the 'derecho' of 12-13 June 2013, which was observed along the US East Coast, has been investigated by Lipa et al. Probably for the first time, a meteotsunami on the oceanic shelf was detected using high-frequency (HF) radar technology. Based on the fact that the waves were detected 47 min before reaching the coastline, the authors discuss the possibility of using such a system within a meteotsunami warning system.

Geist et al. developed probabilistic technique to estimate the possible impact of meteotsunamis in coastal areas. Their approach is based on previous frameworks established for both tsunamis and storm surges. The authors document meteotsunami hazard curves for the north-eastern US coast, plotting the annualized rate of exceedance with respect to the maximum wave amplitudes for particular locations along the coast. They found that siteto-site variations in the hazard curves appear to be caused by regional variations in the shelf parameters affecting the Proudman resonant amplification, and the orientations of the coastline and shelf edge influencing the strength and pathway of reflected meteotsunami waves.

\footnotetext{
${ }^{1}$ NTWC $=$ National Tsunami Warning Center, Palmer, Alaska.

${ }^{2}$ ASOS $=$ Automated Surface-Observing System.
} 
High-frequency sea level oscillations at Wells Harbor (Maine, north-eastern US) with periods of a few tens of minutes were examined by Monserrat et al. The oscillations display a prominent tidally modulated response. The harbour is located in a shallow lagoon connected to the open ocean through a narrow channel. The authors, based both on observational results and numerical experiments, demonstrated that the geometry of the lagoon, which significantly varies over a tidal cycle, determines both the resonant periods and the amplification factor of the bay. The results show that when energetic long waves reach the Wells Harbor entrance (as in the case of a tsunami or meteotsunami), the expected response will be significantly stronger during low tide than during high tide.

A revisited study of two large meteotsunami events that hit Chicago in 1954 was conducted by Bechle and $\mathrm{Wu}$. They found that both atmospheric pressure and wind forcing are essential to explain the observed magnitude of the event, in contrast to the initial conclusions that the waves were primarily pressure-driven (Ewing et al. 1954). The results of their study demonstrate that the enclosed Lake Michigan basin retained and focused wave energy, leading to their large magnitude, long duration and destructive nature.

\section{Meteotsunamis in the World Ocean}

Frere et al. examined the influence of a propagating atmospheric disturbance on the generation of high-frequency sea level oscillations along the coasts of Western Europe in June 2011. They found that a pressure anomaly travelling across the area, from south Portugal to the English Channel, appeared to be the source of the observed oscillations. Spectral analyses show a dominant period of 25 min present in almost all data records. The presented historical facts indicate that this kind of event can be potentially lethal or damaging.

Further to the northeast, in the northern Baltic Sea, Pellikka et al. examined four exceptional sea wave events of meteorological origin observed on the Finnish coast in the summers of 2010 and 2011. These events coincided with sudden jumps in surface air pressure recorded at coastal observation stations, which propagated over the sea with a resonant speed coinciding with the long-wave speed in this region, indicating the Proudman resonance as the forcing mechanism for generation of observed anomalous meteotsunami waves.

Air pressure measurements between 2009 and 2011 over a triangle of microbarographs have been used by Vilibić et al. for detecting strong air pressure disturbances and assessing their possibility to generate substantial meteotsunamis. They found little or no meteotsunami potential in the observed strongest disturbances, pointing out that only strong disturbances with specific parameters can produce destructive meteotsunamis and such disturbances should be considered as rare events.

Tanaka et al. extensively investigated a meteotsunami (locally known as 'abiki') that in February 2009 hit two bays in the western part of Kyushu Island, Japan. They analyzed atmospheric and sea level data collected during the event and found that 'abiki' waves were caused by a sequence of pressure disturbances that produced strongly amplified oscillations in the bays with periods of 12 and 24 min. Very similar results they obtained from numerical experiments. The authors found that a number of continuous pressure disturbances were required to generate the observed anomalous oscillations and that the persistence of the pressure disturbances is important for higher amplification inside complex bays. 
Destructive tsunami-like waves that hit the village of Dwarskersbos, South Africa, on 27 August 1969, were examined and numerically modelled by Okal et al. A field survey revealed maximum runup as large as $2.9 \mathrm{~m}$, with considerable waves observed over an extremely short segment of coastline, less than $2 \mathrm{~km}$ in length. The characteristics of the event were found to be incompatible both with generation by a seismic source and a submarine landslide. By contrast, the wave can be explained as a meteotsunami resulting from resonance between a meteorological squall propagating at $18 \mathrm{~m} / \mathrm{s}$ along an azimuth of $101^{\circ}$ and a gravity wave propagating in the shallow waters off the affected area.

The impact of meteorological tsunamis in the statistics of storm surge trends in the Mar del Plata region, Argentina, is discussed by Dragani et al. They concluded that there is no significant difference between statistics calculated with and without filtering the meteorological tsunami signal from sea level records. Only moderate meteotsunamis were present during the investigated period of 2010-2013; however, strong meteotsunamis, which may account for $30 \%$ of the tidal signal, may have noteworthy influence on the statistics.

Pattiaratchi and Wijeratne used long-term tide gauge data to identify the occurrence, characteristics and origin of meteotsunamis along the coast of Western Australia. Their results indicate that they occur quite frequently and have significant heights; in summer, they typically coincide with thunderstorms and during the winter period with the passage of low-pressure systems. In contrast to the Dragani et al. results, Pattiaratchi and Wijeratne found that the storm surge estimated heights may be strongly reduced (up to $85 \%$ ) by subtracting meteotsunamis from the series. They also indicated that the most destructive meteotsunami events have amplitudes twice the local tidal amplitudes. Air pressure disturbances were found to propagate over the continental shelf along the mainland coastline of Western Australia generating meteotsunamis at various sites.

Acknowledgments We, the Guest Editors, would like to thank Paul Whitmore, who was spiritus movens for this special issue and for creation of NOAA meteotsunami funding opportunity, which leaded to the realization of the TMEWS project. He also reviewed the Editorial and his comments improved the quality of the text. The TMEWS (Towards a meteotsunami warning system along the US coastline, http://jadran.izor. hr/tmews) project was funded by NOAA, Award No. NA11NWS4670005. Tad Murty, the Editor-in-Chief of Natural Hazards, and Petra van Steenbergen, Senior Publishing Editor, Earth Sciences and Geography, Springer, are acknowledged for arranging and encouraging us to organize this topical issue on meteotsunami. We also thank Bhavani Sridhar at Journals Editorial Office of Springer for her editorial assistance. We especially would like to acknowledge Fred Stephenson who reviewed, edited and polished many papers in this issue. Finally, we would like to thank all the authors and reviewers who contributed to this topical issue. Work on this issue by Ivica Vilibić is supported by Ministry of Science, Education and Sports of the Republic of Croatia and by Alexander B. Rabinovich is partly supported by RFBR Grants 12-05-00733-a and 12-05-00757-a.

\section{References}

Akamatsu H (1982) On seiches in Nagasaki Bay. Pap Meteorol Geophys Jpn 33(2):95-115

Belušić D, Grisogono B, Klaić ZB (2007) Atmospheric origin of the devastating coupled air-sea event in the east Adriatic. J Geophys Res 112:D17111. doi:10.1029/2006JD008204

Candela J, Mazzola S, Sammari C, Limeburner R, Lozano CJ, Patti B, Bonnano A (1999) The "Mad Sea" phenomenon in the Strait of Sicily. J Phys Oceanogr 29:2210-2231

Churchill DD, Houston SH, Bond NA (1995) The Daytona Beach wave of 3-4 July 1992: a shallow water gravity wave forced by a propagating squall line. Bull Am Meteorol Soc 76:21-32

Colucci P, Michelato A (1976) An approach to study of the 'Marubbio' phenomenon. Boll Geofis Theor Appl 13(69):3-10 
de Jong MPC, Battjes JA (2004) Low-frequency sea waves generated by atmospheric convection cells. J Geophys Res 109:C01011. doi:10.1029/2003JC001931

de Jong MPC, Holthuijsen LH, Battjes JA (2003) Generation of seiches by cold fronts over the southern North Sea. J Geophys Res 108:3117. doi:10.1029/2002JC001422

Defant A (1961) Physical oceanography, vol 2. Pergamon Press, Oxford, p 729

Donn WL, Balachandran NK (1969) Coupling between a moving air-pressure disturbance and the sea surface. Tellus 21:701-706

Donn WL, McGuinness WT (1960) Air-coupled long waves in the ocean. J Meteorol 17:515-521

Ewing M, Press F, Donn WL (1954) An explanation of the Lake Michigan wave of 26 June 1954. Science 120:684-686

Gomis D, Monserrat S, Tintoré J (1993) Pressure-forced seiches of large amplitude in inlets of the Balearic Islands. J Geophys Res 98:14437-14445

González JI, Farreras SF, Ochoa J (2001) Seismic and meteorological tsunami contributions in the Manzanillo and Cabo San Lucas seiches of September 14, 1995. Mar Geod 24:219-227

Goring DG (2005) Rissaga (long-wave events) on New Zealand's eastern seaboard: a hazard for navigation. In: Proceedings 17th Australasian coastal ocean engineering conference, Adelaide, Australia, 20-23 Sept 2005, pp 137-141

Greenspan HP (1956) The generation of edge waves by moving pressure disturbance. J Fluid Mech $1: 575-592$

Hibiya T, Kajiura K (1982) Origin of "Abiki'" phenomenon (kind of seiches) in Nagasaki Bay. J Oceanogr Soc Jpn 38:172-182

Hodžić M (1979/1980) Occurrences of exceptional sea-level oscillations in the Vela Luka Bay (in Croatian). Priroda 68: 52-53

Jansà A, Monserrat S, Gomis D (2007) The rissaga of 15 June 2006 in Ciutadella (Menorca), a meteorological tsunami. Adv Geosci 12:1-4

Liu PLF, Monserrat S, Marcos M, Rabinovich AB (2003) Coupling between two inlets: observation and modeling. J Geophys Res 108(C3):3069. doi:10.1029/2002JC001478

Marcos M, Monserrat S, Medina R, Orfila A, Olabarrieta M (2009) External forcing of meteorological tsunamis at the coast of the Balearic Islands. Phys Chem Earth 34:938-947

Mecking JV, Fogarty CT, Greatbatch RJ, Sheng J, Mercer D (2009) Using atmospheric model output to simulate the meteorological tsunami response to Tropical Storm Helene (2000). J Geophys Res 114:C10005. doi:10.1029/2009JC005290

Mercer D, Sheng J, Greatbatch RJ, Bobanović J (2002) Barotropic waves generated by storms moving rapidly over shallow water. J Geophys Res 107(C10):3152. doi:10.1029/2001JC001140

Monserrat S, Thorpe AJ (1996) Use of ducting theory in an observed case of gravity waves. J Atmos Sci 53:1724-1736

Monserrat S, Ibberson A, Thorpe AJ (1991) Atmospheric gravity waves and the "rissaga" phenomenon. Q J Roy Meteorol Soc 117:553-570

Monserrat S, Rabinovich AB, Casas B (1998) On the reconstruction of the transfer function for atmospherically generated seiches. Geophys Res Lett 25(12):2197-2200

Monserrat S, Vilibić I, Rabinovich AB (2006) Meteotsunamis: atmospherically induced destructive ocean waves in the tsunami frequency band. Nat Hazards Earth Syst Sci 6:1035-1051

Nomitsu T (1935) A theory of tsunamis and seiches produced by wind and barometric gradient. Mem Coll Sci Imp Univ Kyoto A 18(4):201-214

Orlić M (1980) About a possible occurrence of the Proudman resonance in the Adriatic. Thalass Jugosl 16:79-88

Orlić M, Belušić D, Janeković I, Pasarić M (2010) Fresh evidence relating the great Adriatic surge of 21 June 1978 to mesoscale atmospheric forcing. J Geophys Res 115:C06011. doi:10.1029/2009JC005777

Pasquet S, Vilibić I (2013) Shelf edge reflection of atmospherically generated long ocean waves along the central U.S East Coast. Cont Shelf Res 66:1-8

Pasquet S, Vilibić I, Šepić J (2013) A survey of strong high-frequency sea level oscillations along the U.S. East Coast between 2006 and 2011. Nat Hazards Earth Syst Sci 13:473-482

Paxton CH, Sobien DA (1998) Resonant interaction between an atmospheric gravity wave and shallow water wave along Florida's west coast. Bull Am Meteorol Soc 79:2727-2732

Proudman J (1929) The effect on the sea of changes in atmospheric pressure. Mon Not R Astr Soc Geophys Supp 2:197-209

Rabinovich AB (2009) Seiches and harbor oscillations. In: Kim YC (ed) Handbook of coastal and ocean engineering. World Scientific Publishing, Singapore, pp 193-236

Rabinovich AB, Monserrat S (1996) Meteorological tsunamis near the Balearic and Kuril Islands: descriptive and statistical analysis. Nat Hazards 13(1):55-90 
Rabinovich AB, Monserrat S (1998) Generation of meteorological tsunamis (large amplitude seiches) near the Balearic and Kuril Islands. Nat Hazards 18(1):27-55

Rabinovich AB, Vilibić I, Tinti S (2009) Meteorological tsunamis: atmospherically induced destructive ocean waves in the tsunami frequency band. Phys Chem Earth 34(17-18):891-893

Renault L, Vizoso G, Jansà A, Wilkin J, Tintoré J (2011) Toward the predictability of meteotsunamis in the Balearic Sea using regional nested atmosphere and ocean models. Geophys Res Lett 38:L10601

Sallenger AH Jr, List JH, Gelfenbaum G, Stumpf RP, Hansen M (1995) Large wave at Daytona Beach, Florida, explained as a squall-line surge. J Coast Res 11:1383-1388

Šepić J, Vilibić I (2011) The development and implementation of a real-time meteotsunami warning network for the Adriatic Sea. Nat Hazards Earth Syst Sci 11:83-91

Šepić J, Vilibić I, Belušić D (2009) The source of the 2007 Ist meteotsunami (Adriatic Sea). J Geophys Res 114:C03016. doi:10.1029/2008JC005092

Skamarock WC, Klemp JB (2008) A time-split nonhydrostatic atmospheric model for weather research and forecasting applications. J Comput Phys 227:3465-3485

Tanaka K (2010) Atmospheric pressure-wave bands around a cold front resulted in a meteo-tsunami in the East China Sea in February 2009. Nat Hazards Earth Syst Sci 10:2599-2610

Thomson RE, Rabinovich AB, Krassovski MV (2007) Double jeopardy: concurrent arrival of the 2004 Sumatra tsunami and storm-generated waves on the Atlantic coast of the United States and Canada. Geophys Res Lett 34:L15607. doi:10.1029/2007GL030685

Tintoré J, Gomis D, Alonso S, Wang DP (1988) A theoretical study of large sea level oscillations in theWestern Mediterranean. J Geophys Res 93:10797-10803

Vennell R (2007) Long barotropic waves generated by a storm crossing topography. J Phys Oceanogr $37: 2809-2823$

Vilibić I (2005) Numerical study of the Middle Adriatic coastal waters sensitivity to the various air pressure travelling disturbances. Ann Geophys 23:3569-3578

Vilibić I (2008) Numerical simulations of the Proudman resonance. Cont Shelf Res 28:574-581

Vilibić I, Domijan N, Orlić M, Leder N, Pasarić M (2004) Resonant coupling of a traveling air-pressure disturbance with the east Adriatic coastal waters. J Geophys Res 109:C10001. doi:10.1029/ 2004JC002279

Vilibić I, Horvath K, Strelec Mahović N, Monserrat S, Marcos M, Amores A, Fine I (2014) Atmospheric processes responsible for generation of the 2008 Boothbay meteotsunami. Nat Hazards (this issue). doi:10.1007/s11069-013-0811-y

Vučetić T, Vilibić I, Tinti S, Maramai A (2009) The Great Adriatic flood of 21 June 1978 revisited: an overview of the reports. Phys Chem Earth 34:894-903

Wang X, Li K, Yu Z, Wu J (1987) Statistical characteristics of seiches in Longkou Harbour. J Phys Oceanogr 17:1963-1966 